\title{
Rhizobium alkalisoli sp. nov., isolated from Caragana intermedia growing in saline-alkaline soils in the north of China
}

\author{
Yang Li Lu, ${ }^{1,2}$ Wen Feng Chen, ${ }^{1,2}$ Li Li Han, ${ }^{1,2}$ En Tao Wang ${ }^{3}$ \\ and Wen Xin Chen ${ }^{1,2}$ \\ 'State Key Laboratory for Agrobiotechnology, College of Biological Sciences, China Agricultural \\ University, Beijing 100193, PR China \\ ${ }^{2}$ Key Laboratory of Agro-Microbial Resource and Application, Ministry of Agriculture, Beijing \\ 100193, PR China \\ ${ }^{3}$ Departamento de Microbiología, Escuela Nacional de Ciencias Biológicas, Instituto Politécnico \\ Nacional, México D. F. 11340, Mexico
}

Correspondence

Wen Xin Chen

wenxin@cau.edu.cn
Rhizobia are Gram-negative soil bacteria that mainly cause the formation of root nodules on legumes and fix nitrogen (diazotrophy) inside the nodules. Currently, more than 50 rhizobial species have been described in the classes Alphaproteobacteria and Betaproteobacteria. Rhizobium, a genus in the Alphaproteobacteria, was named a century ago and at the time of writing contained at least 16 nitrogenfixing species including the recently described species Rhizobium miluonense ( $\mathrm{Gu}$ et al., 2008) and Rhizobium multihospitium (Han et al., 2008).

The GenBank/EMBL/DDBJ accession numbers for the partial $16 \mathrm{~S}$ rRNA, atpD, recA, glnll, nod $\mathrm{C}$ and nifH gene sequences of strain CCBAU 01393 ${ }^{\top}$ are EU074168, EU672461, EU672490, EU672475, EU872245 and EU872238, respectively; those of strain CCBAU 01389 are EU872220, EU872226, EU872252, EU872232, EU872246 and EU872239, respectively; and those of strain CCBAU 03239 are EU872221, EU872227, EU872253, EU872233, EU872247 and EU872240, respectively.

Phylogenetic trees based on nod $\mathrm{C}$ and nifH genes, and a phenogram derived from UPGMA/SSM analysis and SDS-PAGE analysis of wholecell soluble proteins of strains CCBAU $01393^{\top}$, CCBAU 01389 and CCBAU 03239 and related species are available as supplementary material with the online version of this paper.
Caragana is a legume genus with about 100 species and about 70 species have been recorded in China. These Caragana species are ecologically important because of their capacity to form nitrogen-fixing nodules with rhizobia.

In the course of a study of rhizobia nodulating Caragana species in China, 174 strains were isolated and classified in the genera Bradyrhizobium, Mesorhizobium and Rhizobium by using $16 \mathrm{~S}$ rRNA gene sequence analysis and other polyphasic taxonomical methods (Lu et al., 2009). Among the strains that were classified in the genus Rhizobium, three of them (CCBAU 01393 ${ }^{\mathrm{T}}$, CCBAU 01389 and CCBAU 03239) isolated from saline-alkaline soils in the north of China formed a distinctive 16S rRNA gene type. These three strains together with other related Rhizobium species were characterized further in the present study by comparison of their whole-cell soluble proteins using SDSPAGE, and housekeeping gene $(\operatorname{atp} D, \operatorname{rec} A$ and $g \ln I I)$ sequences, symbiotic gene (nodC and nifH) sequences, and DNA-DNA hybridization, phenotypic characteristic determination and nodulation tests on various legumes. Rhizobia were isolated from root nodules and were 
purified using the standard procedure on yeast-mannitol agar (YMA) (Vincent, 1970). All strains were cultured on YMA (Vincent, 1970) at $28{ }^{\circ} \mathrm{C}$ and maintained at $4{ }^{\circ} \mathrm{C}$ for temporary storage.

About 1350 bp of the 16S rRNA gene was amplified and sequenced for strains CCBAU $01393^{\mathrm{T}}$, CCBAU 01389 and CCBAU 03239 using the primers $\mathrm{P} 1$ and P6 according to Tan et al. (1997). The sequences were aligned with those of related Rhizobium species using the CLUSTAL W program in the MEGA 4.0 software (Tamura et al., 2007). Aligned sequences were analysed using the same software to produce a Jukes-Cantor distance (Munro, 1969) and to construct an optimal unrooted tree using the neighbourjoining (Saitou \& Nei, 1987) and maximum-parsimony methods. The robustness of the tree topologies was calculated by bootstrap analysis based on 1000 replications of the sequences (Felsenstein, 1985). All the three strains isolated from Caragana had identical 16S rRNA gene sequences and were closely related to $R$. huautlense $\mathrm{SO}_{2}{ }^{\mathrm{T}}$ and R. galegae USDA $4128^{\mathrm{T}}$ (Fig. 1a), with 99.7 and $99.5 \%$ gene sequence similarity, respectively (Table 1). The percentage 16S rRNA gene similarities between the new isolates and the type strains of recognized Rhizobium species with values equal to or higher than $97 \%$ are shown in Table 1.

SDS-PAGE of whole-cell soluble proteins has been used widely in rhizobial taxonomy and is suitable for grouping strains at species level (Diouf et al., 2000; Tan et al., 1997; Wang et al., 2007). Preparation and electrophoresis of the soluble proteins were performed according to Tan et al. (1997). Normalized densitometric traces of the electrophoretic protein patterns were grouped using the GelCompar II software package (Applied Maths). The similarity between each pair of samples (strains) was expressed by using the Dice coefficient and a UPGMA dendrogram was constructed (Vauterin \& Vauterin, 1992). The whole-cell soluble proteins of strains CCBAU $01393^{\mathrm{T}}$, CCBAU 01389 and CCBAU 03239 and the four reference
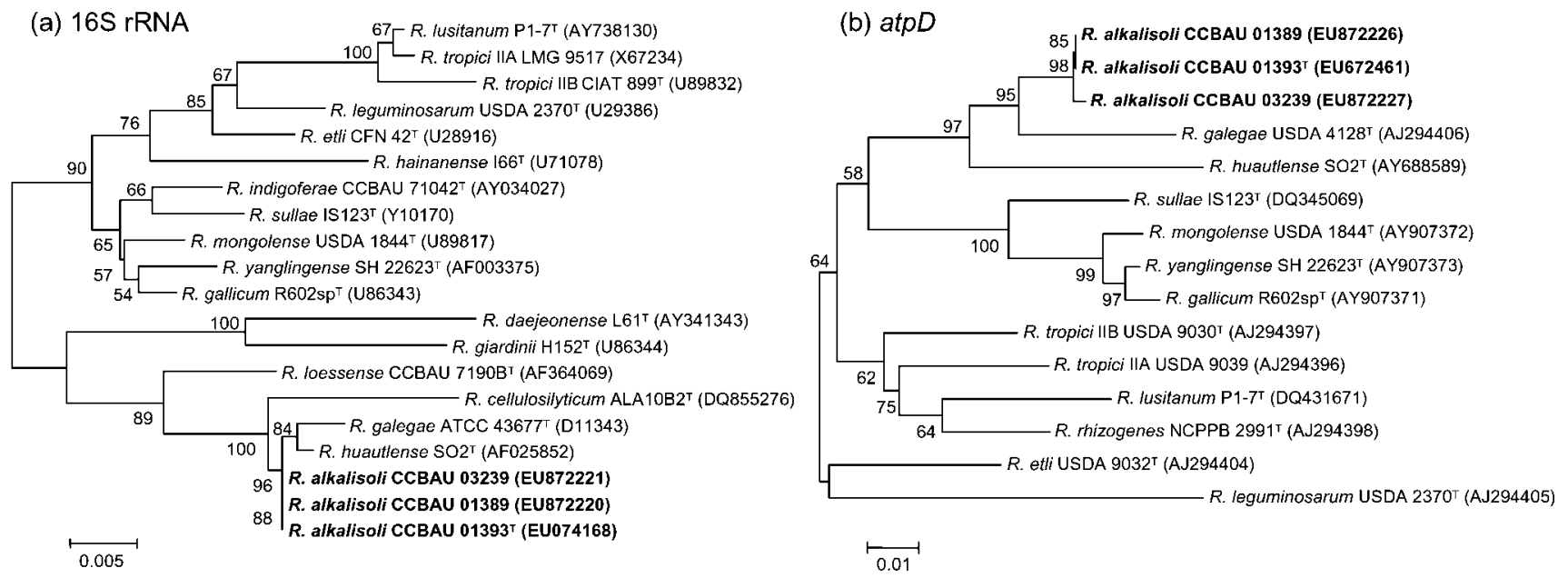

(c) $\operatorname{rec} A$
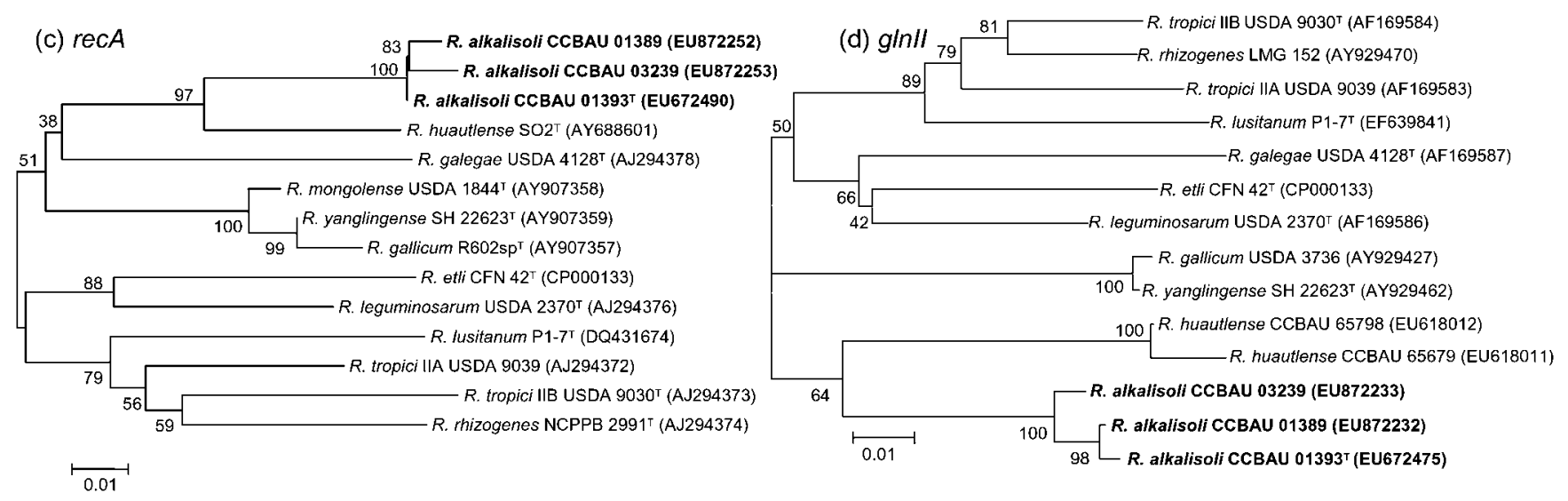

Fig. 1. Comparison of $16 \mathrm{~S}$ rRNA (a), atpD (b), recA (c) and $g / n / l(d)$ gene phylogenies, showing the relationships among the novel group (Rhizobium alkalisoli sp. nov.) (in bold) and recognized Rhizobium species. Trees were constructed by using the neighbour-joining method with a Jukes-Cantor distance matrix. Bootstrap values (\%) based on 1000 replicates are shown at each node. Bars, 0.005 or 0.01 expected changes per site. 
Table 1. Sequence similarities for $16 \mathrm{~S}$ rRNA, atpD, recA, glnIl, nodC, nifH genes and DNA-DNA relatedness (\%) among strains of the novel group and reference strains

NA, Not available.

\begin{tabular}{|c|c|c|c|c|c|}
\hline \multirow[t]{2}{*}{ Strain } & \multicolumn{5}{|c|}{ Strain CCBAU $01393^{T}$} \\
\hline & $r r s$ & $\operatorname{atpD}$ & $\operatorname{rec} A$ & $g \ln I I$ & DNA-DNA relatedness \\
\hline CCBAU 01389 & 100 & 100 & 99.4 & 99.6 & 97.2 \\
\hline CCBAU 03239 & 100 & 99.8 & 99.1 & 98.3 & 92.4 \\
\hline R. huautlense $\mathrm{SO} 2^{\mathrm{T}}$ & 99.7 & 93.5 & 92.8 & NA & 34.9 \\
\hline R. galegae USDA $4128^{\mathrm{T}}$ & 99.5 & 95.4 & 87.6 & 87.6 & 20.5 \\
\hline R. gallicum USDA $2918^{\mathrm{T}}$ & 96.8 & 89.1 & 86.5 & 87.9 & 13.7 \\
\hline R. leguminosarum USDA $2370^{\mathrm{T}}$ & 95.7 & 86.2 & 86.2 & 90.8 & 8.2 \\
\hline R. cellulosilyticum ALA10B $2^{\mathrm{T}}$ & 98.5 & NA & NA & NA & NA \\
\hline R. loessense CCBAU $7190 \mathrm{~B}^{\mathrm{T}}$ & 98.3 & NA & NA & NA & 15.2 \\
\hline
\end{tabular}

strains of related Rhizobium species (Table 2) were subjected to SDS-PAGE analysis. The strikingly similar protein patterns observed among the novel strains indicated considerable homogeneity (see Supplementary Fig. S1, available in IJSEM Online), but they were not duplicate isolates because they were isolated from different sites (Table 2). The protein patterns of reference strains of recognized Rhizobium species were quite different from those of the novel strains (Supplementary Fig. S1, in IJSEM Online).

Housekeeping genes, including $a t p D, \operatorname{rec} A$ and $g \ln I I$, are being used increasingly for protein-coding interspersing throughout the genome. These genes were used to investigate the phylogeny of the bacteria in order to complete that of the 16S rRNA gene (Gaunt et al., 2001; Turner \& Young, 2000; Vinuesa et al., 2005). In this study, PCR amplification and sequencing of partial atpD (510 bp) and $\operatorname{rec} A(530 \mathrm{bp})$ genes were undertaken according to Gaunt et al. (2001), and a 660 bp intragenic fragment of glnII was amplified according to Turner \& Young (2000). Sequence similarities of $a t p D, \operatorname{rec} A$ and $g \ln I I$ genes among the strains isolated in this study and reference strains are given in Table 1. Neighbour-joining trees constructed based on these sequences are shown in Fig. 1. Strains CCBAU $01393^{\mathrm{T}}$, CCBAU 01389 and CCBAU 03239 showed high similarities with each other among the three housekeeping genes (Table 1). They were also closely related to $R$. huautlense and $R$. galegae in the phylogenetic trees based on atpD and recA genes, with 93.5 and $95.4 \%$ $(a t p D)$ and 92.8 and $87.6 \%$ (recA) similarity, respectively (Table 1), supported by bootstrap values of 97 and $95 \%$, which were congruent with the $16 \mathrm{~S}$ rRNA gene tree (Fig. 1a). In the $g \ln I I$ tree (Fig. 1d), the three Caragana rhizobial strains were adjacent to $R$. huautlense CCBAU 65798 and 65679 (no $g \ln I I$ sequence of the type strain $R$. huautlense $\mathrm{SO} 2^{\mathrm{T}}$ was available from the public database), but were further removed from $R$. galegae. Considering all the sequences, the strains in the novel group formed a phylogenetic cluster distinct from recognized species of Rhizobium.

Symbiotic genes (nodC and nifH) and the formation of effective nitrogen-fixing nodules on legumes are important features of rhizobia. Analyses of the rhizobial symbiotic genes could reveal their evolutionary history and host plant ranges. In this study, partial symbiotic genes nodC (about $900 \mathrm{bp}$ ) and nifH (about $760 \mathrm{bp}$ ) of strains CCBAU $01393^{\mathrm{T}}$, CCBAU 01389 and CCBAU 03239 were amplified by using the primer pairs nodCF/nodCI and nifHF/nifHI with the PCR conditions described by Laguerre et al. (2001). In the phylogenetic trees based on nodC genes

Table 2. Isolates and reference strains used in this study

\begin{tabular}{|c|c|c|c|}
\hline Strain & Host plant & Geographical origin & Reference \\
\hline \multicolumn{4}{|l|}{ Rhizobium alkalisoli sp. nov. } \\
\hline CCBAU $01393^{\mathrm{T}}$ & Caragana intermedia & Inner Mongolia, China & This study \\
\hline CCBAU 01389 & Caragana intermedia & Inner Mongolia, China & This study \\
\hline CCBAU 03239 & Caragana intermedia & Shanxi, China & This study \\
\hline \multicolumn{4}{|l|}{ Reference strains } \\
\hline R. huautlense $\mathrm{SO} 2^{\mathrm{T}}$ & Sesbania herbacea & Mexico & Wang et al. (1998) \\
\hline R. galegae HAMBI $540^{\mathrm{T}}\left(=\mathrm{USDA} 4128^{\mathrm{T}}\right)$ & Galega orientalis & Finland & Lindström (1989) \\
\hline R. gallicum USDA $2918^{\mathrm{T}}$ & Phaseolus vulgaris & France & Amarger et al. (1997) \\
\hline R. leguminosarum USDA $2370^{\mathrm{T}}$ & Pisum sativum & USA & Frank (1889) \\
\hline
\end{tabular}


(Supplementary Fig. S2a, available in IJSEM Online), the three Caragana rhizobia strains clustered within a separate branch and were most close to Rhizobium loessense CCBAU 03019 and R. mongolense CCBAU 01546, whose host plants were Astragalus dahuricus and Astragalus membranaceus, respectively (Zhao et al., 2008). The genus Astragalus together with Caragana belong to the same subtribe Astragalinae (Polhill, 1994) and this may account for the reason that they could be infected by rhizobia with a similar nodC gene. The phylogenetic tree based on nifH genes (Supplementary Fig. S2b, in IJSEM Online) also confirmed the close relationship between the rhizobial symbiotic genes and their host ranges. Gueldenstaedtia multiflora, a host for Rhizobium yanglingense $\mathrm{SH} 22623^{\mathrm{T}}$, is also a member of the subtribe Astragalinae (Polhill, 1994). In addition, data from the symbiotic $(\operatorname{nod} C$ or $n i f H)$ and the housekeeping gene analyses agreed with the hypothesis of different evolutionary histories between symbiotic genes and genomic background housekeeping (such as atpD, recA and $g \ln I$ ) and rrs genes (Chen et al., 2008; Ueda et al., 1995).

Cross-nodulation tests were performed among strains CCBAU $01393^{\mathrm{T}}$, CCBAU 01389 and CCBAU 03239 with the hosts of origin or related hosts: Glycyrrhiza uralensis, Caragana microphylla, Astragalus adsurgens, Vigna unguiculata, Vigna radiata, Glycine max, Trifolium pratense, Melilotus alba, Amorpha fruticosa, Lespedeza cuneata, Dunbaria rotundifolia, Vicia septum and the recommended plant species Leucaena leucocephala, Phaseolus vulgaris, Pisum sativum and Medicago sativa (Graham et al., 1991). The representative strain of the novel group, CCBAU $01393^{\mathrm{T}}$, could induce effective nodules on Caragana microphylla, Phaseolus vulgaris and Vigna radiata, but not on the other legumes tested.

DNA-DNA hybridization is considered as a necessary and standard method for defining bacterial species (Graham et al., 1991; Wayne et al., 1987). In this study, total DNA extracted from each strain using the method of Marmur (1961) was used for hybridization with the spectrophotometric method (De Ley et al., 1970). DNA-DNA hybridization was performed between strain CCBAU $01393^{\mathrm{T}}$ and related reference strains (Table 1). All the experiments were performed three times and the mean DNA-DNA relatedness values were used. The range of the standard deviation was $1.47-5.54 \%$ and the mean value was $3.68 \%$. Strain CCBAU $01393^{\mathrm{T}}$ showed similarities of 92-97\% with strains CCBAU 01389 and CCBAU 03239 and had similarities of $8.2-34.9 \%$ with the reference strains of recognized species (Table 1), indicating that the three strains represent a single genomic species but differ from recognized species based on the recommendation of a threshold value of $70 \%$ DNA-DNA relatedness for definition of novel genomic species (Graham et al., 1991; Wayne et al., 1987). The DNA G+C contents were determined using the thermal denaturation method $\left(T_{\mathrm{m}}\right)$ with Escherichia coli K-12 as a standard (Marmur \& Doty, 1962). Strains CCBAU $01393^{\mathrm{T}}$, CCBAU 01389 and CCBAU
03239 had DNA G+C contents of 65.47, 65.21 and $64.87 \mathrm{~mol} \%$, respectively, in the range expected for Rhizobium (Jordan, 1984).

Colony morphologies of the isolates as well as morphology of Hucker's Gram- and Shaeffer-Fulton's spore stained smears were examined. Phenotypic features of the novel group (strains CCBAU $01393^{\mathrm{T}}$, CCBAU 01389 and CCBAU 03239) were determined in comparison with related Rhizobium species according to method described by Gao et al. (1994). The features determined included the utilization of sole carbon and nitrogen sources, resistance to antibiotics and tolerance to $\mathrm{NaCl}$, and $\mathrm{pH}$ and temperature ranges for growth (Gao et al., 1994). Biochemical tests including catalase and oxidase production, methyl red and Voges-Proskauer reaction, and hydrolysis of casein, gelatin, starch, DNA and Tween 80 were performed according to Smibert \& Krieg (1994). Production of hydrogen sulfide $\left(\mathrm{H}_{2} \mathrm{~S}\right)$ from cysteine and of indole from tryptophan were determined as described by Barrow \& Feltham (1993). Differential characteristics of strains CCBAU $01393^{\mathrm{T}}$, CCBAU 01389 and CCBAU 03239 are shown in Table 3 and in the species description.

Based on all the results obtained, strains CCBAU $01393^{\mathrm{T}}$, CCBAU 01389 and CCBAU 03239 are considered to represent a novel species that could be differentiated from closely related Rhizobium species by means of the polyphasic taxonomic methods used, including SDSPAGE of cellular soluble proteins, biochemical characteristics, DNA-DNA relatedness and genotypic comparison of housekeeping and symbiotic genes. The name Rhizobium alkalisoli sp. nov. is proposed for this novel symbiotic bacterial species.

\section{Description of Rhizobium alkalisoli sp. nov.}

Rhizobium alkalisoli [al.ka.li.so'li. N.L. n. alkali (from Arabic al-qaliy), alkali; L. n. solum soil; N.L. gen. n. alkalisoli of alkaline soil, referring to the fact that the bacterium was isolated from Caragana intermedia grown in saline-alkali soil].

Cells are Gram-negative, aerobic, motile, non-spore-forming rods, $0.3-0.5 \mu \mathrm{m}$ wide and 1-3 $\mu \mathrm{m}$ long. Colonies on YMA medium are circular, convex, white and opaque, with a diameter of 1-2 mm within 2-3 days at $28{ }^{\circ} \mathrm{C}$. Growth occurs on YMA agar in $0-3 \% \mathrm{NaCl}$ (optimum, $1 \%$ ). Growth occurs at $12-37^{\circ} \mathrm{C}$ and $\mathrm{pH}$ 5-10 on YMA, with optimum growth at $28{ }^{\circ} \mathrm{C}$ and $\mathrm{pH}$ 7.0. Catalase, urease and oxidase are present, but not L-phenylalaninase. Nitrate is not reduced and reduction of methyl blue is not observed. Nile blue reduction is observed. Lactic acid production, reduction of litmus and acid curd formation are produced in litmus milk tests. Does not hydrolyse gelatin, casein, starch, DNA or Tween 80. Indole is produced, but not $\mathrm{H}_{2} \mathrm{~S}$, and the VogesProskauer and methyl red reaction are negative. Resistant to $\left(\mu \mathrm{g} \mathrm{ml} \mathrm{m}^{-1}\right)$ : ampicillin (300), kanamycin sulfate (50), neomycin sulfate (5), streptomycin sulfate (5), bacitracin (300), erythromycin (50) and chloramphenicol (5). Growth 
Table 3. Differential characteristics of $R$. alkalisoli sp. nov. and closely related recognized Rhizobium species

Strains: 1, CCBAU $01393^{\mathrm{T}}$, CCBAU 01389 and CCBAU $03239(R$. alkalisoli sp. nov.); $2, R$. huautlense $\mathrm{SO} 2^{\mathrm{T}} ; 3, R$. galegae USDA $4128^{\mathrm{T}}$; 4, R. gallicum USDA $2918^{\mathrm{T}}$; 5 , R. leguminosarum USDA $2370^{\mathrm{T}}$. +, Positive; - , negative. Concentrations of carbon and nitrogen sources are $0.1 \%(\mathrm{w} / \mathrm{v})$.

\begin{tabular}{|c|c|c|c|c|c|}
\hline Characteristic & 1 & 2 & 3 & 4 & 5 \\
\hline \multicolumn{6}{|c|}{ Substrates used as sole carbon source } \\
\hline D-Arabinose & + & + & + & + & - \\
\hline Calcium gluconate & - & + & + & - & - \\
\hline Calcium malonate & - & + & - & - & - \\
\hline Dulcitol & - & + & - & + & - \\
\hline meso-Erythritol & + & - & - & + & + \\
\hline Melibiose & - & + & + & - & - \\
\hline Melezitose & + & - & - & - & - \\
\hline Sodium pyruvate & + & + & + & + & - \\
\hline Salicin & + & + & - & + & - \\
\hline D-Ribose & + & + & + & + & - \\
\hline Sodium formate & - & - & - & + & - \\
\hline D-Xylose & - & + & + & + & + \\
\hline Glycine & - & + & + & - & - \\
\hline L-Proline & + & + & - & + & - \\
\hline \multicolumn{6}{|c|}{ Substrates used as sole nitrogen source } \\
\hline D-Glutamic acid & + & + & + & - & - \\
\hline D-Threonine & + & - & + & - & - \\
\hline L-Methionine & + & + & + & + & - \\
\hline \multicolumn{6}{|l|}{ Resistant to $\left(\mu \mathrm{g} \mathrm{ml}^{-1}\right)$ : } \\
\hline Ampicillin (50) & + & - & + & + & - \\
\hline Ampicillin (100) & + & - & + & - & - \\
\hline Ampicillin (300) & + & - & + & - & - \\
\hline Kanamycin sulfate $(50)$ & + & - & + & - & - \\
\hline Streptomycin sulfate (5) & + & - & + & + & - \\
\hline Bacitracin (300) & + & - & + & + & + \\
\hline Erythromycin (50) & + & + & + & - & - \\
\hline Bismarck brown $(0.1 \%)$ & + & + & + & - & - \\
\hline Erythrosin B $(0.1 \%)$ & + & - & + & + & - \\
\hline Neutral red $(0.1 \%)$ & + & - & + & - & - \\
\hline Sodium nitrite $(0.1 \%)$ & - & + & + & - & - \\
\hline $\mathrm{NaCl}(1 \%)$ & + & + & + & - & + \\
\hline $\mathrm{NaCl}(2 \%)$ & + & + & + & - & - \\
\hline $\mathrm{NaCl}(3 \%)$ & + & - & - & - & - \\
\hline $\mathrm{pH} 10.0$ & + & + & - & - & + \\
\hline
\end{tabular}

occurs on YMA with Bismarck brown $(0.1 \%)$, congo red $(0.1 \%)$, erythrosin $\mathrm{B}(0.1 \%)$, neutral red $(0.1 \%)$ and sodium deoxycholate $(0.1 \%)$. Utilizes D-arabinose, Dfructose, D-galactose, D-mannose, melezitose, D-ribose, Dsorbitol, DL-malate, glucose, inositol, L-methionine, Lrhamnose, L-proline, meso-erythritol, raffinose, salicin, sodium citrate, D-sodium gluconate, sodium maltose, sodium pyruvate, sodium succinate, sucrose and trehalose as sole carbon sources, and (+)-L-aspartic acid, (+)-Lglutamic acid, D-glutamic acid, DL-alanine, D-threonine, glycine, hypoxanthine, L-arginine, L-cystine, L-hydroxyproline, L-isoleucine, L-lysine, L-phenylalanine, L-threonine and
L-valine as sole nitrogen sources. Does not utilize adipic acid, vanillic acid, calcium gluconate, calcium malonate, Damygdalin, melibiose, D-xylose, dextrin, DL-asparagine, dulcitol, glycine, inulin, L-arginine, L-threonine, sodium acetate, sodium formate, sodium tartrate, soluble starch, sorbose or syringic acid as sole carbon sources. The $\mathrm{G}+\mathrm{C}$ content of the type strain is $65.47 \mathrm{~mol} \%\left(T_{\mathrm{m}}\right)$.

The type strain, CCBAU $01393^{\mathrm{T}}\left(=\mathrm{LMG} 24763^{\mathrm{T}}=\right.$ HAMBI $3051^{\mathrm{T}}$ ), was isolated from nodules of Caragana intermedia grown in saline-alkaline soils in Qingshuihe city, Inner Mongolia, China.

\section{Acknowledgements}

This work was financed by the National Natural Science Foundation of China (project no. 30870004 and 30670001), National Program for Basic S \& T Platform Construction (no. 2005DKA21201-10) and National Basic Research Program of China (2006CB100206, 2006AA10A213). We would like to thank Professor J. P. Euzéby for his suggestion on the spelling of the specific epithet and to Professor Janet J. Sprent for her embellishment of the manuscript. Many thanks to $\operatorname{Dr} \mathrm{X}$. H. Sui for her patient and diligent work on the preservation of rhizobia and management of the culture collection of Beijing Agricultural University (CCBAU).

\section{References}

Amarger, N., Macheret, V. \& Laguerre, G. (1997). Rhizobium gallicum sp. nov. and Rhizobium giardinii sp. nov., from Phaseolus vulgaris nodules. Int J Syst Bacteriol 47, 996-1006.

Barrow, G. I. \& Feltham, R. K. A. (1993). In Cowan and Steel's Manual for the Identification of Medical Bacteria, pp. 230-231. Cambridge: Cambridge University Press.

Chen, W. F., Guan, S. H., Zhao, C. T., Yan, X. R., Man, C. X., Wang, E. T. \& Chen, W. X. (2008). Different Mesorhizobium species associated with Caragana carry similar symbiotic genes and have common host ranges. FEMS Microbiol Lett 283, 203-209.

De Ley, J., Cattoir, H. \& Reynaerts, A. (1970). The quantitative measurement of DNA hybridization from renaturation rates. Eur $J$ Biochem 12, 133-142.

Diouf, A., de Lajudie, P., Neyra, M., Kersters, K., Gillis, M., MartinezRomero, E. \& Gueye, M. (2000). Polyphasic characterization of rhizobia that nodulate Phaseolus vulgaris in West Africa (Senegal and Gambia). Int J Syst Evol Microbiol 50, 159-170.

Felsenstein, J. (1985). Confidence limits on phylogenies: an approach using the bootstrap. Evolution 39, 783-791.

Frank, B. (1889). Über die Pilzsymbiose der Leguminosen. Ber Dtsch Bot Ges 7, 332-346 (in German).

Gao, J. L., Sun, J. G., Li, Y., Wang, E. T. \& Chen, W. X. (1994). Numerical taxonomy and DNA relatedness of tropical rhizobia isolated from Hainan province, China. Int J Syst Bacteriol 44, 151158.

Gaunt, M. W., Turner, S. L., Rigottier-Gois, L., Lloyd-Macgilp, S. A. \& Young, J. P. W. (2001). Phylogenies of atpD and recA support the small subunit rRNA-based classification of rhizobia. Int J Syst Evol Microbiol 51, 2037-2048.

Graham, P. H., Sadowsky, M. J., Keyser, H. H., Barnet, Y. M., Bradley, R. S., Cooper, J. E., De Ley, D. J., Jarvis, B. D. W., Roslycky, E. B. \& other authors (1991). Proposed minimal standards for the 
description of new genera and species of root- and stem-nodulating bacteria. Int J Syst Bacteriol 41, 582-587.

Gu, C. T., Wang, E. T., Tian, C. F., Han, T. X., Chen, W. F., Sui, X. H. \& Chen, W. X. (2008). Rhizobium miluonense sp. nov., a symbiotic bacterium isolated from Lespedeza root nodules. Int J Syst Evol Microbiol 58, 1364-1368.

Han, T. X., Wang, E. T., Wu, L. J., Chen, W. F., Gu, J. G., Gu, C. T., Tian, C. F. \& Chen, W. X. (2008). Rhizobium multihospitium sp. nov., isolated from multiple legume species native of Xinjiang, China. Int $J$ Syst Evol Microbiol 58, 1693-1699.

Jordan, D. C. (1984). Family III. Rhizobiaceae Conn 1938, $321^{\mathrm{AL}}$. In Bergey's Manual of Systematic Bacteriology, vol. 1, pp. 234-256. Edited by N. R. Krieg \& J. G. Holt. Baltimore: Williams \& Wilkins.

Laguerre, G., Nour, S. M., Macheret, V., Sanjuan, J., Drouin, P. \& Amarger, N. (2001). Classification of rhizobia based on nodC and nifH gene analysis reveals a close phylogenetic relationship among Phaseolus vulgaris symbionts. Microbiology 147, 981-993.

Lindström, K. (1989). Rhizobium galegae, a new species of legume root nodule bacteria. Int J Syst Bacteriol 39, 365-367.

Lu, Y. L., Chen, W. F., Wang, E. T., Guan, S. H., Yan, X. R. \& Chen, W. X. (2009). Genetic diversity and biogeography of rhizobia associated with Caragana species in three ecological regions of China. Syst Appl Microbiol 32, 351-361.

Marmur, J. (1961). A procedure for the isolation of deoxyribonucleic acid from microorganisms. J Mol Biol 3, 208-218.

Marmur, J. \& Doty, P. (1962). Determination of the base composition of deoxyribonucleic acid from its thermal denaturation temperature. J Mol Biol 5, 109-118.

Munro, H. N. (1969). Evolution of protein molecules. In Mammalian Protein Metabolism, 21-132. Edited by H. N. Munro. New York: Academic Press.

Polhill, R. M. (1994). Classification of the Leguminosae and synopsis of legume genera. In Phytochemical Dictionary of the Leguminosae, vol. 1, pp. xxxv-lvii. Edited by F. A. Bisby, J. Buckingham \& J. B. Harborne. London: Chapman and Hill.

Saitou, N. \& Nei, M. (1987). The neighbor-joining method: a new method for reconstructing phylogenetic trees. Mol Biol Evol 4, 406425.

Smibert, R. M. \& Krieg, N. R. (1994). Phenotypic characterization. In Methods for General and Molecular Bacteriology, pp. 607-654. Edited by P. Gerhardt, R. G. E. Murray, W. A. Wood \& N. R. Krieg. Washington, DC: American Society for Microbiology.
Tamura, K., Dudley, J., Nei, M. \& Kumar, S. (2007). MEGA4: Molecular Evolutionary Genetics Analysis (MEGA) software version 4.0. Mol Biol Evol 24, 1596-1599.

Tan, Z. Y., Xu, X. D., Wang, E. T., Gao, J. L., Martinez-Romero, E. \& Chen, W. X. (1997). Phylogenetic and genetic relationships of Mesorhizobium tianshanense and related rhizobia. Int J Syst Bacteriol 47, 874-879.

Turner, S. L. \& Young, J. P. W. (2000). The glutamine synthetases of rhizobia: phylogenetics and evolutionary implications. Mol Biol Evol 17, 309-319.

Ueda, T., Suga, Y., Yahiro, N. \& Matsuguchi, T. (1995). Phylogeny of Sym plasmids of rhizobia by PCR-based sequencing of a nodC segment. J Bacteriol 177, 468-472.

Vauterin, L. \& Vauterin, P. (1992). Computer-aided objective comparison of electrophoresis patterns for grouping and identification of microorganisms. Eur Microbiol 1, 37-41.

Vincent, J. M. (1970). The cultivation, isolation and maintenance of rhizobia. In A Manual for the Practical Study of the Root-Nodule Bacteria, pp. 1-13. Edited by J. M. Vincent. Oxford: Blackwell Scientific.

Vinuesa, P., Silva, C., Werner, D. \& Martínez-Romero, E. (2005). Population genetics and phylogenetic inference in bacterial molecular systematics: the roles of migration and recombination in Bradyrhizobium species cohesion and delineation. Mol Phylogenet Evol 34, 29-54.

Wang, E. T., van Berkum, P., Beyene, D., Sui, X. H., Dorado, O., Chen, W. X. \& Martínez-Romero, E. (1998). Rhizobium huautlense sp. nov., a symbiont of Sesbania herbacea that has a close phylogenetic relationship with Rhizobium galegae. Int J Syst Bacteriol 48, 687-699.

Wang, F. Q., Wang, E. T., Liu, J., Chen, O., Sui, X. H., Chen, W. F. \& Chen, W. X. (2007). Mesorhizobium albiziae sp. nov., a novel bacterium that nodulates Albizia kalkora in a subtropical region of China. Int J Syst Evol Microbiol 57, 1192-1199.

Wayne, L. G., Brenner, D. J., Colwell, R. R., Grimont, P. A. D., Kandler, O., Krichevsky, M. I., Moore, L. H., Moore, W. E. C., Murray, R. G. E. \& other authors (1987). International Committee on Systematic Bacteriology. Report of the ad hoc committee on reconciliation of approaches to bacterial systematics. Int J Syst Bacteriol 37, 463-464.

Zhao, C. T., Wang, E. T., Chen, W. F. \& Chen, W. X. (2008). Diverse genomic species and evidences of symbiotic gene lateral transfer detected among the rhizobia associated with Astragalus species grown in the temperate regions of China. FEMS Microbiol Lett 286, 263-273. 